\title{
EVALUATION OF Lysinibacillus SP, ISOLATED FROM Coptotermes curvignathus GUT, FOR THE DELIGNIFICATION OF OIL PALM RESIDUES
}

\author{
AVALIAÇÃO DE Lysinibacillus SP, ISOLADO A PARTIR DO INTESTINO DE \\ Coptotermes curvignathus, PARA A DESLIGNIFICAÇÃO DE RESÍDUOS DE ÓLEO \\ DE PALMA (DENDÊ)
}

\begin{abstract}
Fadilah AYERONFE'; Angzzas KASSIM ${ }^{1 *}$; Patricia HUNG²; Hafiz ZAINULABIDIN³; Nadiah ISHAK $^{1}$; Sharfina SYARIFAH ${ }^{1}$; Ashuvila ARIPIN ${ }^{1}$

1. Department of Chemical Engineering Technology, Faculty of Engineering Technology, Universiti Tun Hussein Onn Malaysia, 86400, Johor, Malaysia; 2. Department of Crop Science, Faculty of Agriculture and Food Sciences, Universiti Putra Malaysia 97008, Sarawak, Malaysia; 3. Faculty of Mechanical and Manufacturing Engineering, Universiti Tun Hussein Onn Malaysia, 86400, Johor, Malaysia; oluwatosinfadu@gmail.com, angzzas@uthm.edu.my, patricia@upm.edu.my, nadiah.ishak89@gmail.com, sharfina.sms.20@gmail.com, ashuvila_2329@yahoo.com
\end{abstract}

\begin{abstract}
The application of ligninolytic bacteria and enzymes is a green pre-treatment alternative in the production of paper and biofuel from oil palm residues. In this study we investigated the ability of Lysinibacillus pakistanensis isolated from termite gut in degrading the lignin component of oil palm residues. The residues were biotreated with the bacterial strain in an aerated submerged fermentation system for 7 days at $30{ }^{\circ} \mathrm{C}, \mathrm{pH} 7$ and compared with untreated control. Enzyme activities were determined using specific substrates. Peak lignin peroxidase (377.6 U/L), manganese peroxidase $(218.19 \mathrm{U} / \mathrm{L})$, and laccase $(405.4 \mathrm{U} / \mathrm{L})$ activity were recorded after 4,4, and 5 days of incubation respectively, using oil palm leaf as substrates. Lignin loss of $4.5 \%$, $5.7 \%$ and $6.6 \%$ in oil palm leaf, oil palm trunk and empty fruit bunch respectively was achieved after treatment with the microorganism. SEM images revealed structural changes in the cell wall of the residues. Pre-treatment with this bacterial strain has promising prospects of improving the efficiency of the pulping process in an environmentally safe manner.
\end{abstract}

KEYWORDS: Biodelignification. Oil palm. Pulping. Lignin. Enzymes.

\section{INTRODUCTION}

The pulp and paper industry is one of the high demand sectors, resulting from the accelerating demands for paper-based products. Despite the increasing deployment of paperless communication with the advent of information technology, world paper consumption is continually increasing rather than decreasing as expected (SZABO et al., 2009). The removal of lignin is one of the key processes in paper production as it imparts stiffness on mechanical pulp fibres and yellow coloration on newsprints (PALIWAL et al., 2012). Moreover, the efficient hydrolysis of cellulose either for pulp or biofuel production is contingent upon degradation of lignin. Conventional methods of dissolving lignin in wood involve the use of chemicals and bleaching agents (LIEW et al., 2011; AYERONFE et al., 2018). These processes do not only require high inputs of energy but also produce highly toxic effluents which are not environmental friendly (SUMATHI; HUNG, 2006). The continuous increase in demand for paper products and growing environmental concerns necessitate the need to look towards technological improvement in the conventional pulping methods.

To this effect, research on the use of microbial enzymes as a pre-treatment method has gained interest. Pre-treatments of wood pulp with ligninolytic enzymes might provide milder and cleaner processes of delignification with no substantial loss to cellulose. This will not only save cost and energy, but will also improve the fibre bonding and the quality of paper produced (LIEW et al., 2011; FERRAZ, 2008).

The ligninolytic capabilities of fungi have been explored over the years (CRISTINA et al., 2013, OBRUCA et al., 2012; TANAKA et al. 2012). However, long weeks of incubation and ligninase enzymes expression in fungi being a secondary metabolism have limited its commercial deployment (BUGG et al., 2008). Fungi lack of stability under practical conditions also underscores the need to explore bacterial ligninolytic potential. Exploring the diversity in lignin-degrading environments; such as soils in forestry locations and also in wood digesting insects, may also reveal novel enzymatic activities for lignin degradation (TAYLOR et al., 2012). 
Few reports exist on degradation of lignin by some termites species gut flora (GEIB et al. 2008; Ke et al., 2011). GEIB et al. (2008) demonstrated the depolymerisation, demethylation and ring hydroxylation of lignin by gut microflora of Zootermopsis angusticollis and Anoplophora glabripennis. Sunil et al. (2016) investigated the lignin degrading ability of Trabulsiella $s p$, which was reported to have degraded up to $60 \%$ of guaiacylglycerol- $\beta$-guaiacyl ether (GGE). Lignin degrading capabilities of gut flora of of Rhynchophorus Ferrugineus have also been reported (KASSIM et al., 2016). There are also reports of aromatic degradation capabilities of bacteria isolated from termite guts. An aromaticdegrading strain of Burkholderia and Citrobacter has been isolated from the gut $C$. formosanus (HARAZONO et al., 2003). A strain of Rhodococcus erythropolis capable of degrading polychlorinated biphenyl was isolated from Reticulitermes speratus (CHUNG et al., 1994). These reports put forward the practicability of termite symbiotic systems as screening sources for biocatalysts of industrial interest. However, the integration of enzymes secreted by termites gut microflora in pulping process has not been explored commercially, as much effort have been focused on lignin degradation by fungi (SINGHAL et al., 2015; SINGH et al., 2013)].

Oil palm is an economical perennial crop widely cultivated in West Africa and Southeast Asia. In Malaysia, Oil palm plantation increased from 2.3 million in 1994 to about 3.87 million ha in 2004 and to approximately 4.85 million ha in 2010 (MPOB 2011). As a consequence, the palm oil production has recorded a rocketing upswing over the years, from about 7.8 million tons in 1995 to about 15 million tonnes in 2005 and to 18.8 million tonnes in 2012 (MPOB 2012).

The explosive growth of the oil palm plantation has generated massive amounts of waste which are, at present, not efficiently utilized, thereby creating obstacles in replanting operations and colossal environmental concerns. The exploration of these oil palm residues in the production of value added products will not only help alleviate the disposal and environmental problems associated with it, but as well add value to the creation of rural agricultural-based economy. This study therefore, aimed to explore the green delignification of oil palm residues using bacteria isolated from termite's gut.

\section{MATERIAL AND METHODS}

\section{Microorganism}

Pure cultures of bacterial isolates from Coptotermes curvignathus gut was obtained from the Department of Crop Science, University Putra Malaysia, Sarawak. The isolate was re-streaked on LB agar plate for $24 \mathrm{hrs}$ and used for further analysis. Stock cultures were kept in $25 \%$ glycerol stock.

\section{Screening for lignin degrading potential of the isolate}

The lignin degrading capacity of the isolate was assayed for based on its ability to grow on Mineral salt media (MSM) supplemented with kraft lignin as sole carbon source, as well as its ability to decolorise commercialized dyes. MSM-Lignin agar was prepared according to Bandounas et al. (2011). $200 \mathrm{~mL}$ M9 Salt solution $\left(64 \mathrm{~g} \mathrm{Na}_{2} \mathrm{HPO}_{4} .7 \mathrm{H}_{2} 0,15 \mathrm{~g}\right.$ $\mathrm{KHPO}_{4} .7 \mathrm{H}_{2} \mathrm{O}, 2.5 \mathrm{~g} \mathrm{NaCl}, 5.0 \mathrm{~g} \mathrm{NH}_{4} \mathrm{Cl}, 1 \mathrm{~L} \mathrm{ddH}_{2} 0$ ), $100 \mu \mathrm{L} 1 \mathrm{M} \mathrm{CaCl}, 2 \mathrm{~mL} 1 \mathrm{M} \mathrm{MgSO}_{4}, 5 \mathrm{~g}$ of lignin powder, $15 \mathrm{~g}$ of agar powder, $800 \mathrm{ml}$ of $\mathrm{ddH}_{2} \mathrm{O}$ and autoclaved at $120{ }^{\circ} \mathrm{C}$ for 20 minutes. MSM-lignin agar plates were observed for colonies formation after incubation for 7 days at $37^{\circ} \mathrm{C}$. Un-inoculated MSM-lignin plates served as controls.

The isolates which showed good growth on MSM-Lignin agar were further screened using indicator dyes (methylene blue and azure B) as described by (Bandounas et al., 2011), colonies on MSM-Lignin agar were streaked on LB agar plates supplemented with $2 \mathrm{~g} / \mathrm{l}$ and $2 \mathrm{~g} / \mathrm{l}$ methylene blue and azure $\mathrm{B}$ respectively. The plates were incubated at $37^{\circ} \mathrm{C}$ for $72 \mathrm{hrs}$ and observed for zone of clearance.

\section{Identification of lignin degrading microorganisms}

The Microbial genomic DNA of the isolate was extracted from the pure using DNeasy Qiagen Kit according to manufacturer's instruction. The 16S rRNA gene amplification and sequencing were carried out by First Base Laboratory, Malaysia. The primers 27F (5'-AGAGTTTGATCMTGGCTCAG3') and 1495R (5'-GGTTACCTTGTTACGACTT$3^{\prime}$ ) were used for the amplification of the 16S rRNA gene. The PCR reactions were carried out at $95^{\circ} \mathrm{C}$ for $5 \mathrm{~min}, 30$ cycles of $94^{\circ} \mathrm{C}$ for $40 \mathrm{~s}, 55^{\circ} \mathrm{C}$ for $40 \mathrm{~s}$, $72^{\circ} \mathrm{C}$ for $80 \mathrm{~s}$ and a final extension of $7 \mathrm{~min}$ at $72^{\circ} \mathrm{C}$, The PCR products were analysed on $0.8 \%(\mathrm{w} / \mathrm{v})$ agarose gel and sequenced. All sequences were blasted using BLAST (http://blast.ncbi.nlm.nih.gov/blast/Blast.cgi) against the NCBI 16S ribosomal RNA sequences (Bacteria only) Database, excluding uncultured Bacteria bacterium (taxid: 77133). Sequence data were aligned with software package MEGA and the 
Evaluation of lysinibacillus sp...

Phylogenetic tree was constructed using the neighbour-joining method.

\section{Biodegradation experiment}

The degradation experiment was conducted in an aerated submerged fermentation system (OBRUCA et al., 2012). To evaluate the lignin degrading capacity of the isolate, the isolate was cultured for a period of 7 days in LB medium containing $2 \mathrm{~g}$ (oven dried weight) of the different oil palm residues (oil palm leaf (OPL), empty fruit bunch (EFB) and oil palm trunk (OPT)) as sole substrates. The residues were washed and autoclaved to get rid of contaminants prior to inoculation with the bacterial strain. Cultures were incubated at $30^{\circ} \mathrm{C}$ at $120 \mathrm{rpm}$ for 7 days in an incubator shaker. The control and cultured samples were centrifuged at $5000 \mathrm{rpm}$ for $20 \mathrm{~min}$ to remove biomass and suspended solids. The supernatants containing the crude enzymes extract were used to determine the activity of ligninolytic enzymes.

\section{Ligninolytic enzymes assay}

Lignin peroxidase, LiP activity was measured by monitoring the oxidation of veratryl alcohol to veratryl aldehyde in the presence of $\mathrm{H}_{2} \mathrm{O}_{2}$, this was determined by the increase in absorbance at $310 \mathrm{~nm}$. $(\varepsilon 310=9300 \mathrm{M}-1 \mathrm{~cm}-1)$ in $100 \mathrm{mM}$ citrate buffer ( $\mathrm{pH} 3.0)$ at $30{ }^{\circ} \mathrm{C}$. Manganese peroxidase, MnP activity was assayed spectrophotometrically with phenol red $(\varepsilon 610=22000 \mathrm{M}-1 \mathrm{~cm}-1)$ as substrate in $50 \mathrm{mM}$ sodium lactate at (pH 5.0) $30^{\circ} \mathrm{C}$ (OBRUCA et al., 2012). Laccase activity was measured using 2, 2-azinobis (3ethylbenzthiazoline-6- sulphonic acid) (ABTS) in $0.1 \mathrm{M}$ acetate buffer $(\mathrm{pH} 4.5)$ at $30{ }^{\circ} \mathrm{C}$. Oxidation of ABTS was determined by the increase in A420 $(\varepsilon 420=36,000$ M-1 cm-1) (CHEN et al., 2012). The enzyme activity was expressed in international units (U), defined as the amount of enzyme required to convert $1 \mu$ mole of substrate to product per minute.

\section{Determination of lignin loss}

The lignin content of the control and biotreated biomass was determined prior to and after degradation experiment by treatment with cold sulphuric acid according to T222om-02 test. Percentage lignin loss was calculated as follows (Tappi Test T222om-02):

$\%$ lignin loss $=\frac{\text { lignin content before tratment }- \text { lignin cowtent after tratment }}{\text { lignin contentbaforatratment }} \times 100$

\section{Scanning electron microscopy}

At the end of the degradation experiment, the cultured samples were centrifuged to extract the
AYERONFE; F. et al.

delignified residues. The residues were washed and dried. The dried residues were sputter-coated with gold-palladium alloy to increase conductivity. Morphological changes in the samples, resulting from lignin degradation, were then observed under a scanning electron microscope (Carl Zeiss EVO LS 10).

\section{Statistical analysis}

Data obtained were subjected to analysis of variance (ANOVA, $\mathrm{p}<0.05)$ using appropriate statistical software (Minitab). This test was used to determine the differences between the mean of the samples. The significance of the results was determined using $\mathrm{p}$-value $(\mathrm{p}<0.05)$. The results indicate the mean of three replicates, whereas the error bars in graphs denote standard error.

\section{RESULTS AND DISCUSSION}

\section{Screening and identification of lignin degrading bacteria}

The bacterial strain was selected based on the ability to grow on mineral salt medium supplemented with kraft lignin as sole carbon source, as well as the ability to decolorise industrial dyes evident by the formation of zone of clearance around the plates. The selected bacterial isolate was identified based on 16S rRNA sequencing and was found to exhibit maximum homology with Lysinibacillus pakistanensis. The identification of Lysinibacillus sp from termite gut bacteria has not been reported neither has the ligninolytic potential of this genus been reported. However, Lysinbacillus spp were found to be present in dye contaminated soil (ANJANEYA et al., 2011; Liang et al. 2009). Saratale et al. (2003) isolated Lysinibacillus sp. RGS from dyes contaminated soil, capable of decolorising sulfonated dyes and textile effluents. Chaudhari et al. (2013) also reported the decolourization of reactive Orange M2R dye and chromate reduction by Lysinibacillus sp. KMK-A. These reports lend credence to the insinuation of a possible link between aromatic degradation and lignin metabolism, which is tenable given that much of the aromatic material found in the soil are lignin derivatives.

\section{Enzymes Assay}

The production of ligninolytic enzymes during degradation of oil palm residues by Lysinibacillus sp is being reported for the first time. The result indicates that Lysinibacillus sp can produce the three different ligninolytic enzymes 
(Lignin peroxidase, Manganese and laccase (Figure

1).

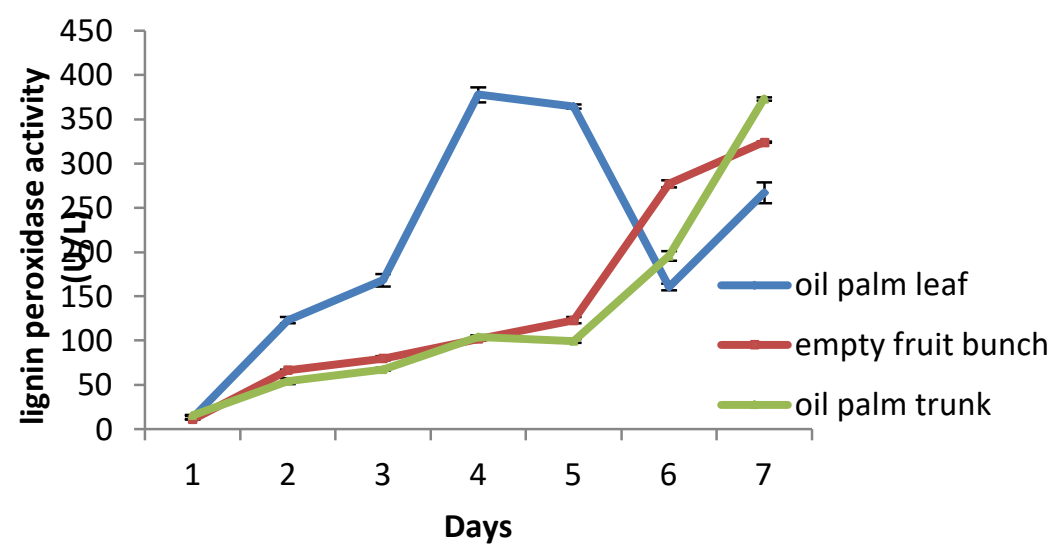

(a)

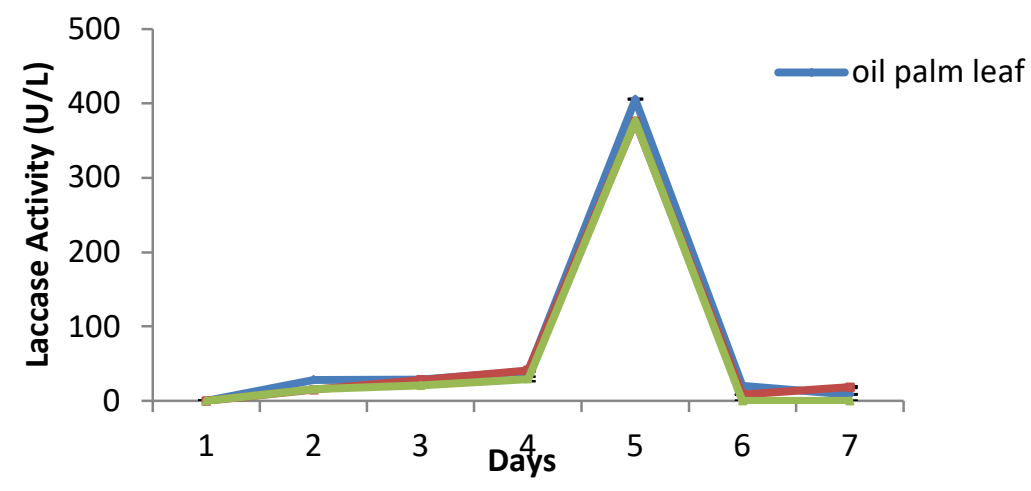

(b)

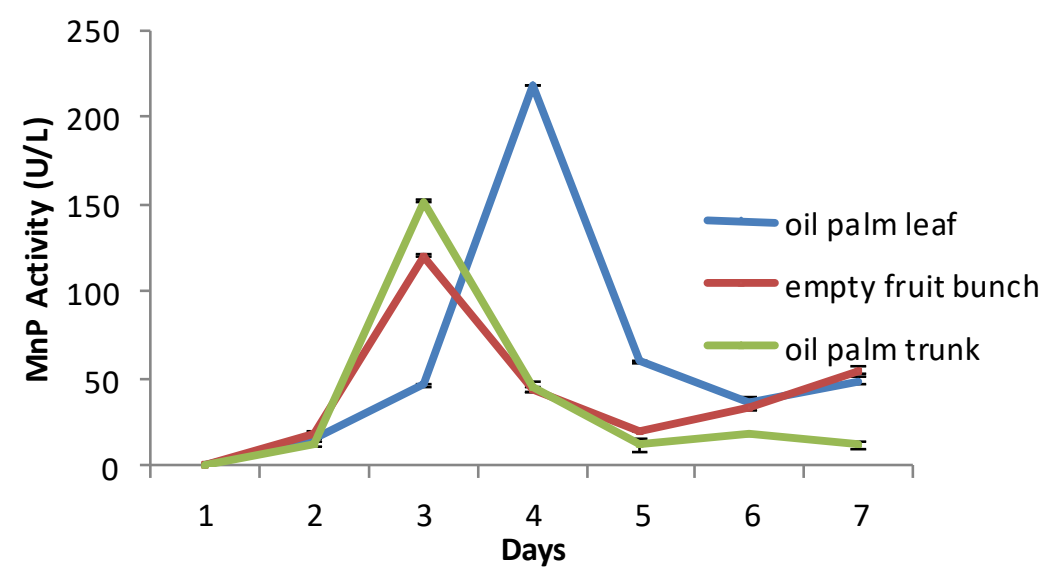

(c)

Figure 1. Lignin peroxidase (a), Laccase (b), and Manganese peroxidase (c) activity profile during the degradation of oil palm residues by Lysinibacillus sp. Results are mean of three independent samples with standard error

However maximal production of lignin peroxidase varies with the substrates used. This variation could be attributed to the differences in the chemical compositions of the substrates. Ligninolytic enzymes production was higher using OPL as substrate than observed using EFB and OPT. The high lignin content of OPL (29.58\%), compared to EFB (20.35\%) and OPT could be a stimulant of ligninolytic enzymes production. This is consistent with a previous study on the production of ligninolytic enzymes by Pleurotus eryngii on agro-industrial wastes (AKPINAR; UREK 2014). It was reported that higher lignin contents in apricot wastes significantly stimulated the lignin 
metabolism when compared to pomegranate wastes. Laccase and lignin peroxidase were the predominating enzymes observed during pretreatment with the bacterial strain. Lacasse activity was undetected after a day of incubation.

However, activity steadily increases in the following 3 days of incubation, reaching maximal (405.4 U/L, 375.56 U/L, 376.66 U/L) in medium supplemented with oil palm leaf, empty fruit bunch and oil palm trunk respectively, after 5 days of incubation (Figure 1). Laccase activity thereafter declined. Decline in activity could result from the build-up of lignin degradation derivatives which may exhibit inhibitory effects on enzyme production. This is consistent with the results obtained during the degradation of kraft lignin by Pandoraea sp. B-6 isolated from bamboo chips. It was reported that laccase activity was maintained at a low level in the initial 2 days of incubation, peak activity (1120.6 U/L) was recorded after 5 days of incubation (Shi et al., 2013). The peak laccase activity after 5 days of incubation also correlates with peak growth/beginning of cell death in the isolates (data not shown). It could be that laccase enzymes mainly functions when the exponential growth of phase is almost over. A similar conclusion was reached in a previous study (Shi et al., 2013). Maximal lignin peroxidase activity was recorded between 4-6 days of incubation. A similar finding was reported during kraft lignin metabolism by bacterial strains isolated from oil palm plantation soils (HASHIMAH et al., 2013). Lignin peroxidase was highest (377.6 U/L) using with oil palm leaf as substrates, as compared to $372.92 \mathrm{U} / \mathrm{L}$ and 324. 16U/L recorded using oil palm trunk and empty fruit bunch respectively. However, in contrast to decline in LiP activity observed during degradation of oil palm leaf, activity increases steadily throughout the degradation experiments using oil palm trunk and empty fruit bunch as substrates. MnP activity increases significantly in the initial 3-4 days of incubation, which was immediately followed by a marked decline. Interestingly, activity steadily increases in the following days of incubation. Decline in activity and a sudden rise in activity could be explained by the breakdown of inhibitory compounds to yield products that can be metabolised by the isolate. Maximal MnP activity observed in the initial 3 and 4 days also shows that manganese peroxidase production is crucial in lignin metabolism by Lysinibacillus $s p$.

\section{Determination of Lignin Loss}

Lignin losses in oil palm leaf, empty fruit bunch and oil palm trunk bio-treated with
Lysinibacillus $s p$ were $4.5 \%, 6.6 \%$ and $5.7 \%$ respectively. The loss in lignin content after degradation experiment could be attributed to the action of the ligninolytic enzymes which have also been implicated in previously reported lignin degradation experiments (KAMSANI et al., 2016; NTOUGIAS et al., 2015). There is a significant difference in the percentages of lignin loss recorded for each residue after treatment with Lysinibacillus sp. This could be due to the structural differences of the lignin component of each residue, as well as the degree of susceptibility of each residue to microbial degradation (SKYBA et al., 2013). Colonization of wood by microorganism facilitates the softening of lignin thereby reducing the input of energy and chemicals required in subsequent pulping process. The higher the lignin loss, the more easily fibres will bleach with the utilization of few chemicals. This will ultimately improve the pulp production economics (FERRAZ et al., 2008; LIEW et al., 2011).

Percentage lignin loss during lignin degradation by white rot fungi on spruce wood shavings ranged from $2.5 \%-7.2 \%$ (FACKLER et al., 2006). However, it took 2 weeks of incubation to achieve such extent of degradation in the fungi studied. Interestingly, only 7 days of incubation was sufficient to record comparable results in the bacterial strains involved in this study. Lignin metabolism being a primary metabolism rather than secondary as reported in fungi is propitious for potential biotechnological applications. Lignin loss of $4 \%$ was also reported during of biopulping of wood chips with Phlebia brevispora after 30 days incubation (FONSECA et al., 2014). Singh et al. (2010) reported a $9.35 \%$ reduction in lignin content of oil palm trunk after 4 weeks of treatment with white-rot fungus Trametes versicolor. $14.5 \%$ wheat straw-lignin was also degraded by Pleurotus eryngii (SKYBA et al., 2013). Nevertheless, production parameters were optimized to enhance lignin metabolism. Higher degradation could also be achieved by the selected bacterial strains in this study with longer incubation periods if production parameters were optimized.

It is intriguing that maximum enzyme production was observed using oil palm leaf as substrates. However, higher lignin degradation was recorded in empty fruit bunch. This could result due to the low lignin content of empty fruit bunch thereby making it easily degraded than others.

The structure of lignin, which is determined by the composition of monolignols, varies between and within species (SKYBA et al., 2013). The susceptibility of wood to degradation is largely 
AYERONFE; F. et al.

dependent on the composition, as well as distribution of lignin in the different cell layers (SKYBA et al., 2013). Moreover, the level of enzymes activity sometimes does not correlate with the degree of lignin loss, which is consistent with previous reports (FACKLER et al., 2006; KNEZEVIC et al., 2013). In some cases, the reduction in the lignin content by the fungal species correlated with the enzymes expression pattern during lignin degradation by white rot fungi on spruce wood shavings (FACKLER et al., 2006). However, it was concluded that the cumulative total peroxidase activity of the fungal cultures after 14 days with the decrease of the lignin content within the same time showed a very low correlation (FACKLER et al., 2006). Percentage lignin loss in Ceriporiopsis subvermispora correlated with increased peroxidase activity after 8 days of cultivation. However, delignification increases despite decreased peroxidase activity in the following days of cultivation. Treatment with Phlebia brevispora resulted in higher reduction in lignin content $(6.2 \%)$, as compared to that with Dichomitus squalens BS1000.73 (4.4\%) even though peroxidase activity in cultures of the latter was 19 fold higher than that observed in the cultures of the former. Knezevic et al. (2013) also reported that significant lignin breakdown seemed to occur in later stages of wheat straw fermentation, even though the peak of enzyme activity was reached much earlier. Apparently, the rate of lignin breakdown is not necessarily correlated with the level of enzyme activity.

\section{Scanning electron microscopy}

To gain insight into the structural changes in the cell wall of the residues, the treated and untreated samples were observed using a scanning electron microscope (Carl Zeiss EVO LS 10) (Figure 2).

The surface morphology of the untreated samples (Fig. 2) appeared more compact and unaltered as opposed the rough and fractured surfaces of the treated samples. This modification could be attributed to the loss of lignin in the treated samples. Similar observations have been reported in previous studies (SINGHAL et al., 2015; SINGH et al., 2013). Interestingly, such structural changes are crucial in pulping processes as less chemicals and energy will be required in subsequent chemical and mechanical pulping process respectively. Formation of pits on the surface of bagasse fibres was reported in the biopulping of bagasse by Cryptococcus albidus (SINGHAL et al., 2015). Alteration in the cell wall of sugarcane bagasse as a result of acidic treatments has also been reported (MORAES ROCHA et al., 2011) 


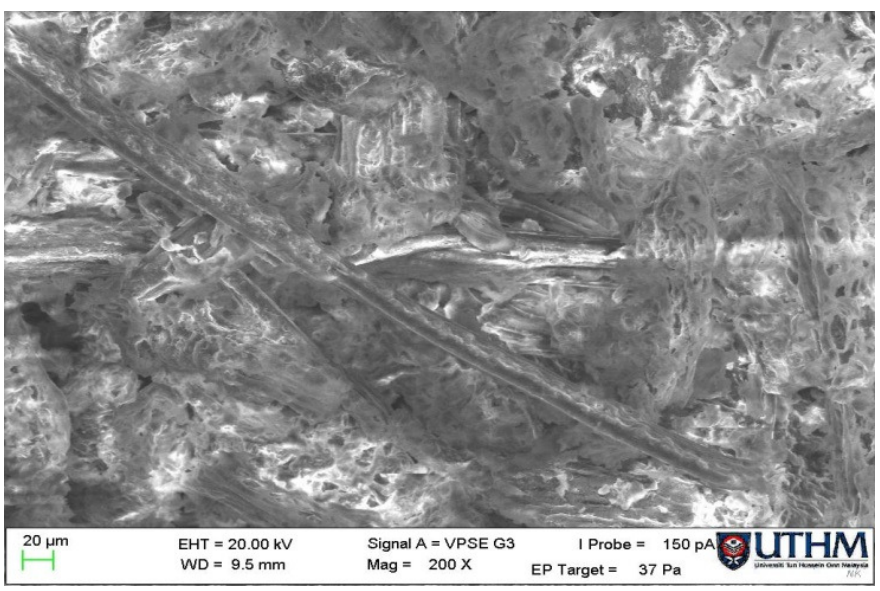

(a)

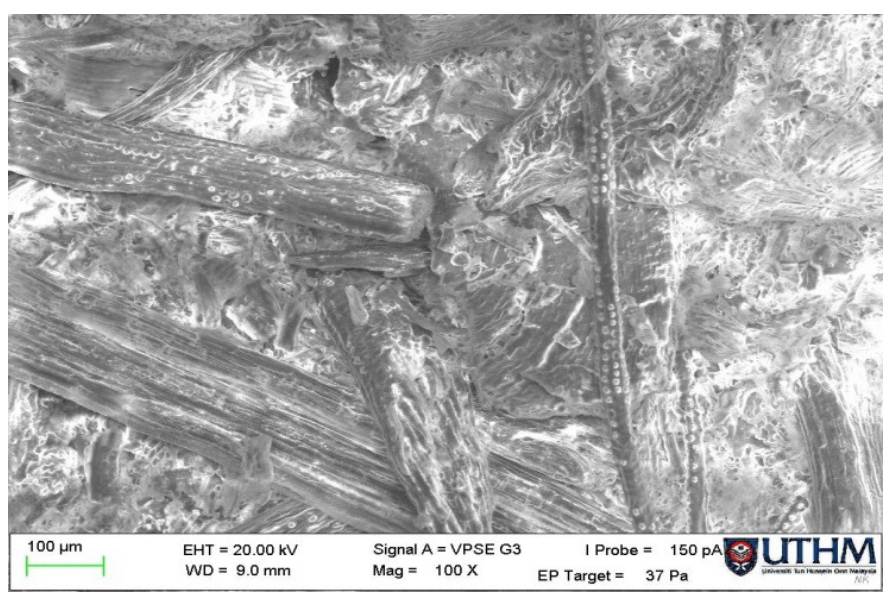

(c)

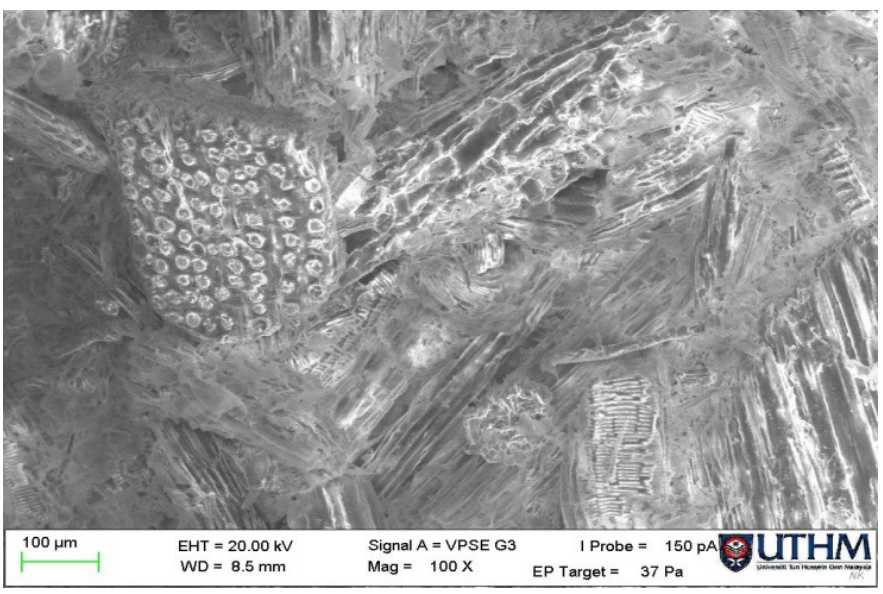

(e)

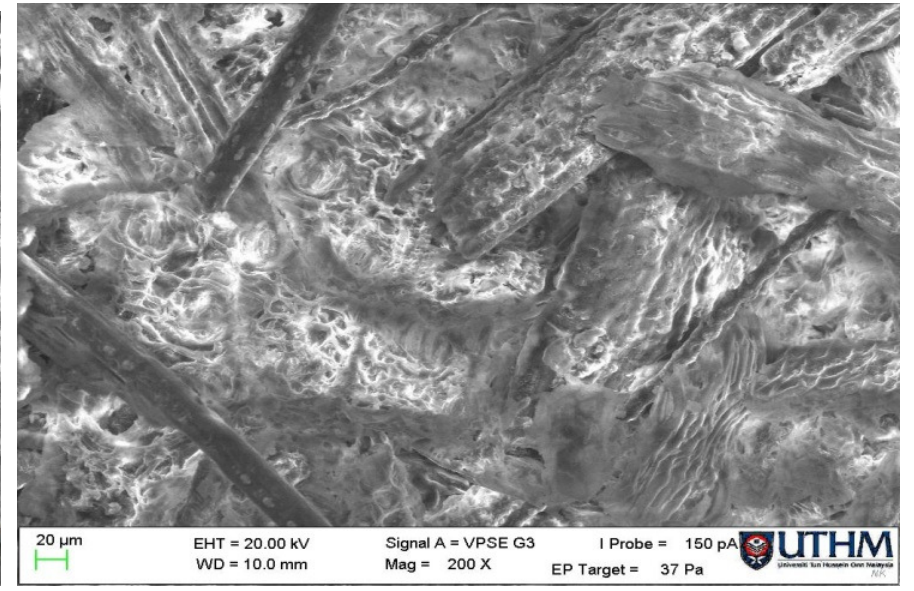

(b)

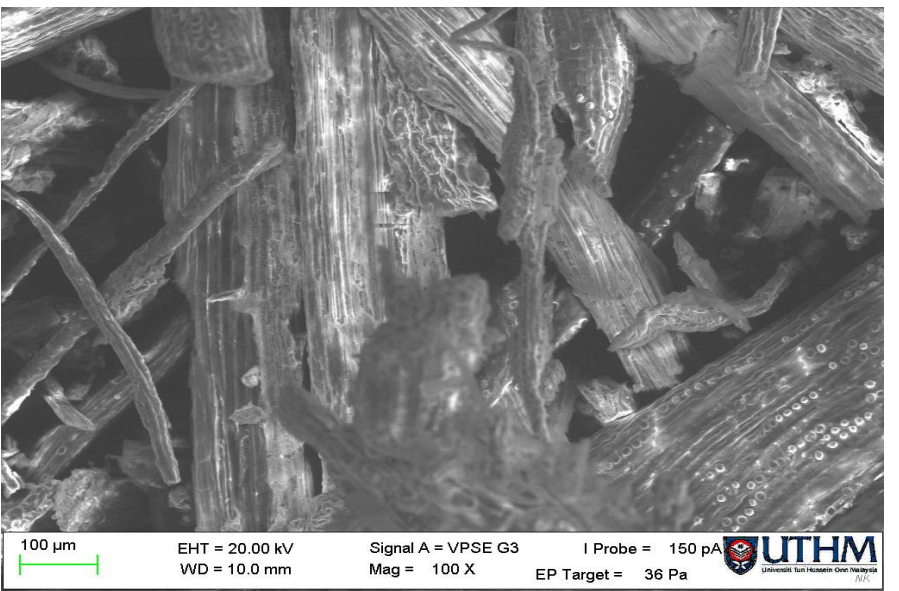

(d)

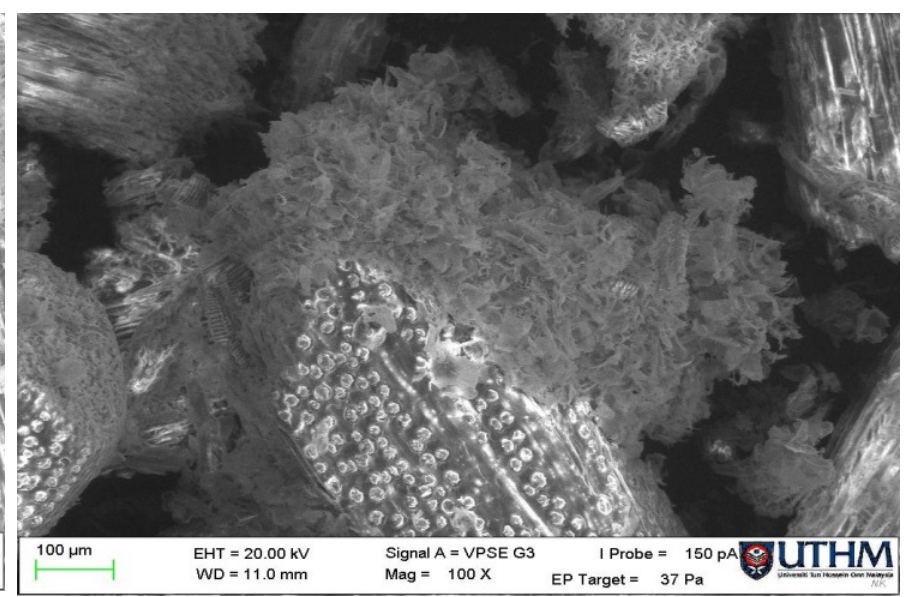

(f)

Figure 2. SEM micrographs of (a) control OPL; (b) biotreated OPL; (c) control EFB; (d) biotreated EFB; (e) control OPT; and (f) biotreated OPT 


\section{CONCLUSIONS}

The application of ligninolytic bacteria and enzymes is a green pre-treatment alternative in the production of paper and biofuel from oil palm residues.

In this study we investigated the ability of Lysinibacillus $s p$ isolated from termite gut in degrading the lignin component of oil palm residues. All three ligninolytic enzymes were expressed by the organism. However, the level of production of the ligninolytic enzymes, LiP, MnP and Lac varies with the different carbon sources. This could be attributed to the nature and components of the different residues. Although, highest enzyme activity was recorded using oil palm leaf as substrate, the highest lignin loss was observed in empty fruit bunch, suggesting that the level of enzyme activities does not necessarily correlate with the extent of lignin degradation. Interestingly, these observations propose the utilization of these residues not only in paper production, but also as substrates in the costeffective production of ligininolytic enzymes for industrial applications. However, optimization of production parameters such as $\mathrm{pH}$, temperature, presence of inducers, is necessary in order to enhance the degradation efficiency of the bacterial strain.

\section{ACKNOWLEDGEMENT}

This research was financially supported by Ministry of Science Technology and Innovation (SO27) and Fundamental Research Grant Scheme (1549). The authors like to thank technicians at the Department of Crop Science laboratory, Universiti Putra Malaysia. We are thankful for their support.

RESUMO: A aplicação de bactérias e enzimas ligninolíticas é uma alternativa verde de pré-tratamento na produção de papel e biocombustível a partir de resíduos de óleo de palma. Neste estudo, investigamos a capacidade de Lysinibacillus pakistanensis isolado do intestino de cupins na degradação do componente de lignina dos resíduos de dendê. Os resíduos foram biotratados com a estirpe bacteriana num sistema de fermentação submersa arejado durante 7 dias a $30^{\circ} \mathrm{C}, \mathrm{pH} 7$ e comparados com controle não tratado. As atividades enzimáticas foram determinadas usando substratos específicos. Pico de lignina peroxidase (377,6 $\mathrm{U} / \mathrm{L})$, peroxidase de manganês $(218,19 \mathrm{U} / \mathrm{L})$ e atividade de lacase $(405,4 \mathrm{U} / \mathrm{L})$ foram registradas após 4,4 e 5 dias de incubação, respectivamente, utilizando como substratos a folha da palmeira de dendê. A perda de lignina de 4,5\%, 5,7\% e 6,6\% na folha da palmeira, no tronco do dendezeiro e cacho de frutas vazio, respectivamente, foi alcançada após o tratamento com o microorganismo. Imagens de MEV revelaram alterações estruturais na parede celular dos resíduos. O pré-tratamento com esta cepa bacteriana tem perspectivas promissoras de melhorar a eficiência do processo de polpação de maneira ambientalmente segura.

PALAVRAS-CHAVE: Biodelignificação. Óleo de palma. Polpação. Lignina. Enzimas.

\section{REFERENCES}

AKPINAR, M.; UREK, R. O. Extracellular ligninolytic enzymes production by Pleurotus eryngii on agroindustrial wastes. Prep Biochem Biotechnol. v. 44, p. 772-781, 2014. (Online) https://doi.org/10.1080/10826068.2013.867870

ANJANEYA, O.; SOUCHE, S. Y.; SANTOSHKUMAR, M.; KAREGOUDAR, T. B. Decolorization of sulfonated azo dye Metanil Yellow by newly isolated bacterial strains : Bacillus sp . strain AK1 and Lysinibacillus sp . strain AK2. J Hazard Mater. v. 190, p. 351-358, 2011. (Online) https://doi.org/10.1016/j.jhazmat.2011.03.044

AYERONFE, F.; KASSIM, A.; ISHAK, N.; ARIPIN, A. HUNG, P.; ABDULKAREEM, M. A Review on Microbial Degradation of Lignin. Advanced Science Letters v. 24(6), p. 4407-4413, 2018. (Online) https://doi.org/10.1166/asl.2018.11615

BANDOUNAS, L.; WIERCKX, N. J.; DE WINDE, J. H.; RUIJSSENAARS, H. J. Isolation and characterization of novel bacterial strains exhibiting ligninolytic potential. BMC Biotechnol. v. 11, p. 94-105, 2011. (Online) https://doi.org/10.1186/1472-6750-11-94 
BUGG, T. D. H.; AHMAD, M.; HARDIMAN, E. M.; SINGH, R. The emerging role for bacteria in lignin degradation and bio-product formation. Curr Opin Biotechnol. v. 22, p. 394-400, 2008.

https://doi.org/10.1016/j.copbio.2010.10.009

CHAUDHARI, A. U.; TAPASE, S. R.; MARKAD, V. L.; KODAM, K. M.;. Simultaneous decolorization of reactive Orange M2R dye and reduction of chromate by Lysinibacillus sp. KMK-A. J Hazard Mater. v. 262 , p. 580-588, 2013. https://doi.org/10.1016/j.jhazmat.2013.09.006

CHEN, Y. H.; CHAI, L. Y.; ZHU, Y. H.; YANG, Z. H.; ZHENG, Y.; ZHANG. H. Biodegradation of kraft lignin by a bacterial strain Comamonas sp. B-9 isolated from eroded bamboo slips. J Appl Microbiol. v. 112, p. 900-906, 2012. https://doi.org/10.1111/j.1365-2672.2012.05275.x

CHUNG, S. Y.; MAEDA, M.; SONG, E.; HORIKOSHI, K.; KUDO, T. A Gram-positive Polychlorinated Biphenyl-degrading Bacterium, Rhodococcus erythropolis Strain TA421, Isolated from a Termite Ecosystem. Biosci Biotechnol Biochem. v. 58, p. 2111-2113. https://doi.org/10.1271/bbb.58.2111

CRISTINA, G.; DE SOUZA, D. F.; CASTOLDI, R. Production of laccase and manganese peroxidase by Pleurotus pulmonarius in solid-state cultures and application in dye decolorization. Folia Microbiol. v. 58, p. 641-647, 2013. https://doi.org/10.1007/s12223-013-0253-7

FACKLER, K.; GRADINGER, C.; HINTERSTOISSER, B.; MESSNER, K.; SCHWANNINGER, M. Lignin degradation by white rot fungi on spruce wood shavings during short-time solid-state fermentations monitored by near infrared spectroscopy. Enzyme Microb Technol. v. 39, p. 1476-1483, 2006.

https://doi.org/10.1016/j.enzmictec.2006.03.043

FERRAZ, A.; GUERRA, A.; MENDONCA, R.; MASARIN, F.; VICENTIM, M. P.; AGUIAR, A. Technological advances and mechanistic basis for fungal biopulping. Enzyme Microb Technol. v. 43, p. 178185, 2008. https://doi.org/10.1016/j.enzmictec.2007.10.002

FONSECA, M. I.; FARINA, J. I.; CASTRILLO, M. L.; RODRÍGUEZ, M. D.; NUNEZ, C. E.; VILLALBA, L. L. Biopulping of wood chips with Phlebia brevispora BAFC 633 reduces lignin content and improves pulp quality. Int Biodeterior Biodegrad. v. 90, p. 29-35, 2014. https://doi.org/10.1016/j.ibiod.2013.11.018

GEIB, S. M.; FILLEY, T. R.; HATCHER, P. G.; HOOVER, K.; CARLSON, J. E.; GASCO, M. J. Lignin degradation in wood-feeding insects. Pro Natl Acad Sci USA. v. 35, p. 2932-12937, 2008. https://doi.org/10.1073/pnas.0805257105

HARAZONO, K.; YAMASHITA, N.; SHINZATO, N.; WATANABE, Y.; FUKATSU, T.; KURANE, R. Isolation and characterization of aromatics-degrading microorganisms from the gut of the lower termite Coptotermes formosanus. Biosci Biotechnol Biochem. v. 67, p. 889-892, 2003.

https://doi.org/10.1271/bbb.67.889

HASHIMAH, N.; RAHMAN, A.; AINI, N.; RAHMAN, A.; AZIZ, S. A.; HASSAN, M. A. Production of Ligninolytic Enzymes by Newly Isolated Bacteria from Palm Oil Plantation Soils. Bioresources. v. 8, p. 6136$6150,2013$.

KAMSANI, N.; SALLEH, M. M.; YAHYA, A.; CHONG, C. S. Production of Lignocellulolytic Enzymes by Microorganisms Isolated from Bulbitermes sp. Termite Gut in Solid-State Fermentation. Waste and Biomass Valor. v. 7, p. 357-371, 2016. https://doi: 10.1007/s12649-015-9453-5

KASSIM, A. S. M.; ISHAK, N.; ARIPIN, A. M.; ZAIDEL, D. N. Potential lignin degraders isolated from the gut of Rhynchophorus Ferrugineus. International Conference on Mechanics, Materials and Structural Engineering (ICMMSE), p. 66-72, 2016. 
KE, J.; SINGH, D.; CHEN, S. Aromatic compound degradation by the wood-feeding termite Coptotermes formosanus (Shiraki). Int Biodeterior Biodegrad. v. 65, p. 744-756, 2011. https://doi.org/10.1016/j.ibiod.2010.12.016

KNEZEVIC, A.; MILOVANOVIC, I.; STAJIC, M.; LONCAR, N.; ILIJA BRCESKI, I.; VUKOJEVIC, J. Lignin degradation by selected fungal species. Bioresour Technol. v. 138, p. 117-123, 2013. https://doi.org/10.1016/j.biortech.2013.03.182

LIANG, B.; LU, P.; LI, H.; LI, R.; LI, S.; HUANG, X. Chemosphere Biodegradation of fomesafen by strain Lysinibacillus sp . ZB-1 isolated from soil. Chemosphere. v. 77, p. 1614-1619, 2009.

https://doi.org/10.1016/j.chemosphere.2009.09.033

LIEW, C. Y.; HUSAINI, A.; HUSSAIN, H.; MUID, S.; LIEW, K. C.; ROSLAN, H. A. Lignin biodegradation and ligninolytic enzyme studies during biopulping of Acacia mangium wood chips by tropical white rot fungi. World J Microbiol Biotechnol. v. 27, p. 1457-1468, 2011. https://link.springer.com/article/10.1007/s11274010-0598-x

MORAES ROCHA, G. J.; MARTIN, C.; SOARES, I. B.; SOUTO MAIOR, A. M.; BAUDEL, H. M.; MORAES DE ABREU, C. A. Dilute mixed-acid pretreatment of sugarcane bagasse for ethanol production. Biomass and Bioenergy. V. 35, p. 663-670, 2011. https://doi.org/10.1016/j.biombioe.2010.10.018

MPOB. Malaysia Palm Oil Board Stat. retrieved 19 Sept. 2016, available on website : http// www.mpob.gov.my, 2011.

MPOB. Malaysia Palm Oil Board Stat. retrieved 19 Sept. 2016. http //www.mpob.gov.my, 2013.

NTOUGIAS, S.; BALDRIAN, P.; EHALIOTIS, C.; NERUD, F.; MERHAUTOVÁ, V.; ZERVAKIS, G. I. Olive mill wastewater biodegradation potential of white-rot fungi - Mode of action of fungal culture extracts and effects of ligninolytic enzymes. Bioresour Technol. v. 189, p. 121-130, 2015.

https://doi.org/10.1016/j.biortech.2015.03.149

OBRUCA, S.; MAROVA, I.; MATOUSKOVA, P; HARONIKOVA, A.; LICHNOVA, A. Production of lignocellulose-degrading enzymes employing Fusarium solani F-552. Folia Microbiol. v. 57, p. 221-227, 2012. https://link.springer.com/article/10.1007/s12223-012-0098-5

PALIWAL, R.; RAWAT, A. P.; RAWAT M, RAI JPN. Bioligninolysis: Recent updates for biotechnological solution. Appl Biochem Biotechnol. v. 167, p. 1865-1889, 2012.

https://link.springer.com/article/10.1007/s12010-012-9735-3

SARATALE, R. G.; GANDHI, S. S.; PURANKAR, M. V.; KURADE, M. B.; GOVINDWAR, S. P.; SANG, E. O. Decolorization and detoxification of sulfonated azo dye C . I . Remazol Red and textile effluent by isolated Lysinibacillus sp . RGS, J Biosci Bioeng. v. 115, p. 658-667, 2013.

https://doi.org/10.1016/j.jbiosc.2012.12.009

SHI, Y.; CHAI, L.; TANG, L.; YANG, Z.; ZHENG, Y.; CHEN, Y. Biochemical investigation of kraft lignin degradation by pandoraea sp. B-6 isolated from bamboo slips. Bioprocess Biosyst Eng. v. 36, p. 1957-1965, 2013. https://link.springer.com/article/10.1007/s00449-013-0972-9

SINGH, P.; SULAIMAN, O.; HASHIM, R.; RUPANI, P. F.; PENG, L. C. Biopulping of lignocellulosic material using different fungal species: A review. Rev Environ Sci Biotechnol. v. 9, p. 141-151, 2010. https://link.springer.com/article/10.1007/s11157-010-9200-0

SINGH, P.; SULAIMAN, O.; HASHIM, R.; PENG, L. C.; SINGH, R. P. Evaluating biopulping as an alternative application on oil palm trunk using the white-rot fungus Trametes versicolor. Int. Biodeterior Biodegrad. v. 82, p. 96-103, 2013. https://doi.org/10.1016/j.ibiod.2012.12.016 
SINGHAL, A.; JAISWAL, P. K.; THAKUR, I. S. Biopulping of bagasse by Cryptococcus albidus under partially sterilized conditions. Int Biodeterior Biodegrad. v. 97, p. 143-150, 2015.

https://doi.org/10.1016/j.ibiod.2014.10.011

SKYBA, O.; DOUGLAS, C. J.; MANSFIELD, S. D. Syringyl-rich lignin renders poplars more resistant to degradation by wood decay fungi. Appl Environ Microbiol. v. 79, p. 2560-2571, 2013.

https://doi.org/10.1128/AEM.03182-12

SUMAN, S. K.; DHAWARIA, M.; TRIPATHI, D.; RATURI, V.; ADHIKARI, D. K.; KANAUJIA, P. K. Investigation of lignin biodegradation by Trabulsiella sp. isolated from termite gut. Int Biodeterior Biodegrad. v. 112, p. 12-17, 2016. https://doi.org/10.1016/j.ibiod.2016.04.036

SUMATHI, S.; HUNG, Y. Treatment of pulp and paper mill wastes. Waste Treat Process Ind. p. 453-497, 2006.

SZABÓ, L.; SORIA, A.; FORSSTRÖM, J.; KERÄNEN, J. T.; HYTÖNEN, E. A world model of the pulp and paper industry: Demand, energy consumption and emission scenarios to 2030. Environ Sci Policy. v. 12, p. 257-269, 2009. https://doi.org/10.1016/j.envsci.2009.01.011

TANAKA, H.; KOIKE, K.; ITAKURA, S.; ENOKI, A. Degradation of wood and enzyme production by Ceriporiopsis subvermispora. Enzyme Microb Technol. v. 45, p. 384-390, 2012.

https://doi.org/10.1016/j.enzmictec.2009.06.003

TAYLOR, C. R.; HARDIMAN, E. M.; AHMAD, M.; SAINSBURY, P. D.; NORRIS, P. R.; BUGG, T. D. H. Isolation of bacterial strains able to metabolize lignin from screening of environmental samples. J Appl Microbiol. v. 113, p. 521-530, 2012. https://doi.org/10.1111/j.1365-2672.2012.05352.x 